\title{
Growth parameters of a benthic suspension feeder along a depth gradient across the pycnocline in the southern Kattegat, Denmark
}

\author{
Alf B. Josefson*, Jørgen N. Jensen, Torkel G. Nielsen, Bjarke Rasmussen \\ National Environmental Research Institute, Department of Marine Ecology and Microbiology, Frederiksborgvej 399, \\ PO Box 358, DK-4000 Roskilde, Denmark
}

\begin{abstract}
Recent findings that a significant part of the pelagic primary production in the Kattegat may occur in the pycnocline raised the question of whether or not this causes increased input of energy to the benthos in the area where the pycnocline comes into contact with the bottom. With this question in mind, comparative studies were made of somatic growth, condition and gut content of the filter feeding bivalve Arctica islandica and of gross community variables of total fauna at stations along a transect across the area where the pycnocline usually has contact with the bottom. Gut content and condition were measured in March/April, May and September 1992, concomitantly with studies of hydrography and pelagic biology. Growth was estimated by measuring internal growth rings in the shells on individuals of different sizes, yielding average estimates from several years. Temporal variation of chlorophyll $a$ in the bottom water and chlorophyll gut content in A. islandica showed a similar pattern with the highest values in March/April and the lowest in September. Growth rates in terms of shell size of premature individuals ( $<6 \mathrm{yr}$ ) were higher at intermediate depths, immediately below pycnocline depth, suggesting enhanced growth conditions in this area. A part of the variation in shell size was apparently due to long-term variations in growth conditions. Data showed low growth rates in 1988 and 1991 and a higher rate in 1990. Enhancement of soft tissue production close to the pycnocline depth was $>100 \%$. The data does not support the expectation of a direct simple relation between pycnocline production and $A$. islandica growth, and different reasons for this are discussed.
\end{abstract}

KEY WORDS: Benthic-pelagic coupling $\cdot$ Pycnocline $\cdot$ Growth $\cdot$ Arctica islandica $\cdot$ Kattegat

\section{INTRODUCTION}

The pycnocline constitutes a major physico-chemical border between different water masses in the Kattegat, separating the low saline Baltic water from the high saline Skagerrak/North Sea water. Recent studies have shown that a significant part of pelagic production may occur in the pycnocline (Richardson \& Christoffersen 1991, Nielsen et al. 1994). The pycnocline is an example of a pelagic frontal area with direct bottom contact.

Although it may be a consensus that the production of benthic macrofauna is often limited by food, such as particulate organic matter (POM) produced in the

\footnotetext{
•E-mail: alf@hami1.dmu.dk
}

water column, little is known about the scales on which this type of pelagic-benthic coupling operates. Since the pycnocline peak in production is a phenomenon which can occur for months each year, it represents a persistent spatial gradient in phytoplankton concentrations, not only in the water column but also along the bottom. The bottom area between 10 and $20 \mathrm{~m}$ depth which is potentially influenced by the pycnocline covers a large part of total bottom area in the Kattegat $(>15 \%)$, and energy flow processes there may be of significance in the Kattegat ecosystem. The opportunity to study the possible influence of a food gradient on the scale of kilometers on benthic productivity is thus available.

Previous studies have assessed the importance of this border, especially the salinity gradient, for species 
composition in the macrobenthic communities (Rosenberg \& Möller 1979), and some studies have connected oxygen depletion with decreased mixing below the pycnocline with wide temporal fluctuations of benthos abundance and biomass as a consequence (Rosenberg \& Loo 1988, Baden et al. 1990, Josefson \& Jensen 1992). No attempts, however, have been made to investigate effects of increased pycnocline phytoplankton biomass on benthic productivity.

In this study we investigate production-related variables, growth, condition and gut content, in the ocean quahog Arctica islandica along a transect from 15 to $33 \mathrm{~m}$ depth extending into the area where the pycnocline comes into contact with the bottom in the southern Kattegat. The main purpose was to investigate if production of this species was stimulated in the area of pycnocline-bottom contact. We chose this particular species for several reasons. (1) It occurs both in the area of pycnocline-bottom contact and outside this area; (2) it is a dominating component of the macrofauna; and (3) it is long-lived and suitable for growth band analysis, which enables growth estimates with great temporal representation.

\section{AREA OF INVESTIGATION}

Samples of bottom fauna were taken at 6 stations in the depth interval 15 to $33 \mathrm{~m}$ along a transect perpendicular to the isobaths in the southern Kattegat in March/April, May and September 1992 (Fig. 1, Table 1). The sediment varied from fine sand at the most shallow stations to sand mixed with silt and clay at the deepest stations. Measurements of oxygen concentrations in the bottom water in March, May and September 1992 never showed values lower than $5 \mathrm{mg} \mathrm{l}^{-1}$ (Nielsen et al. 1994). Parallel studies of hydrography and plankton dynamics (Nielsen et al. 1994, Rasmussen 1994) showed on average a peak of fluorescence at $17 \mathrm{~m}$ depth (Fig. 2), corresponding to Stn H3 (Fig 1).

\section{METHODS}

Profiles of temperature and salinity were recorded throughout the water column using a Neil Brown mark II CTD (conductivity/temperature/depth probe) system. The chlorophyll a fluorescence was measured with a Q-instrument fluorimeter (Hundahl \& Holck 1980) mounted on the CTD. Samples for bottom water chlorophyll $a$ and oxygen were taken with a 51 Niskin water sampler at $0.5 \mathrm{~m}$ above the bottom, 3 times in each of the time periods: 25 March to 1 April, 13 to 20 May, and 2 to 9 September in 1992, at 4 stations identical with stations for benthic sampling, and at 1 station (H4) at $13 \mathrm{~m}$ water depth at the same transect.

Benthic samples were taken with a $0.1 \mathrm{~m}^{2}$ Van Veen grab at the 2 stations with the softest sediments (H1 and $\mathrm{H922}$ ) and with a $0.25 \mathrm{~m}^{2}$ USNEL box-corer at the other stations with harder sediments coincident with sampling of bottom water variables. Benthic samples were sieved through a $2 \mathrm{~mm}$ screen, and the faunal material was immediately deep frozen. Shell length was measured on all individuals of Arctica islandica. A screen size of $2 \mathrm{~mm}$ was considered adequate for the purpose of the study since this would retain $A$. islandica individuals 1 yr or older [the shortest shell distance (height) being $>5 \mathrm{~mm}$; see e.g. Brey et al. 1990] and would allow reasonable estimates of density and biomass of similar sized potentially competing species.

To analyse for gut content of phytoplankton material, the soft parts were fragmentized and put into $96 \%$ alcohol, each clam separately, and left for at least $6 \mathrm{~h}$
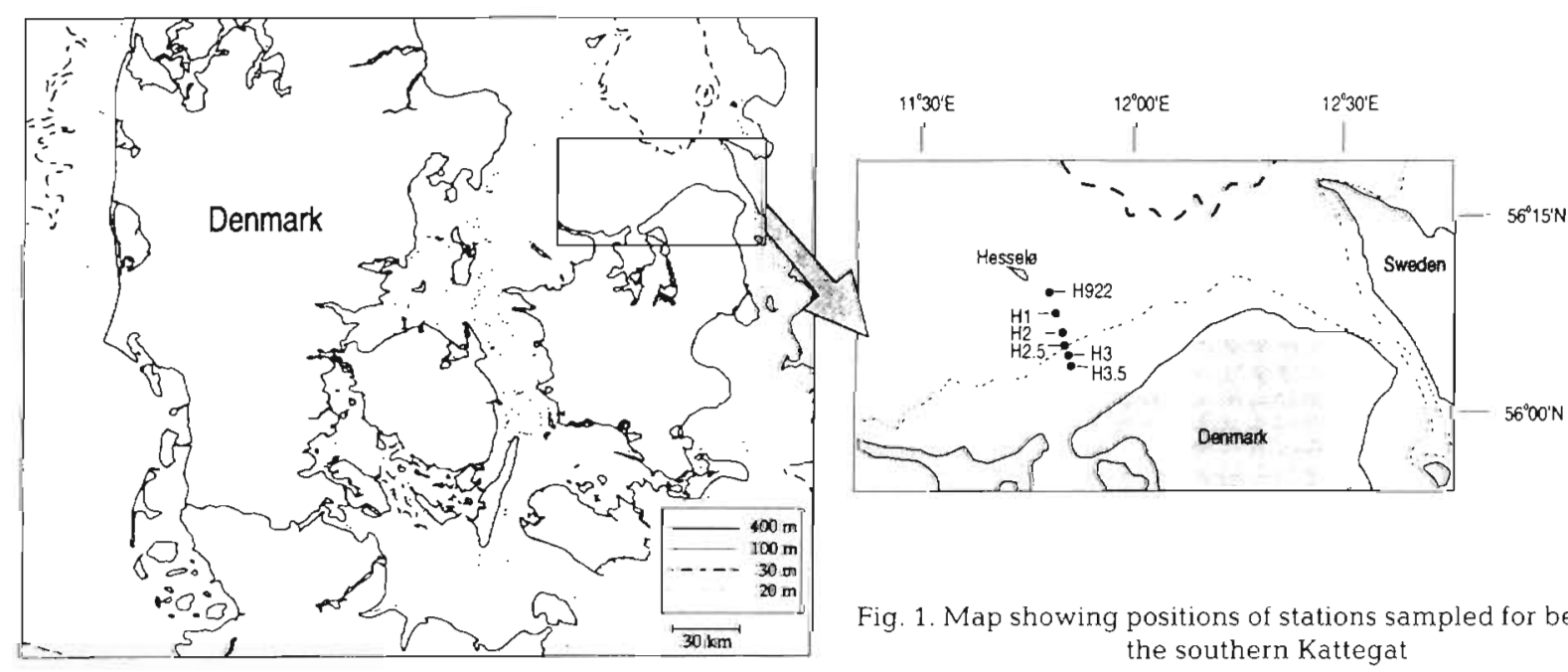

Fig. 1. Map showing positions of stations sampled for benthos in the southern Kattegat 
Table 1. Positions, depths and faunal variables at stations along the Hesselø transect in southern Kattegat in 1992. Ash-free dry weights (AFDW) given in $\mathrm{g} \mathrm{m}^{-2}$ and filtration capacity (FC) in $\mathrm{l} \mathrm{h}^{-1} \mathrm{~m}^{-2}$. Standard deviation in parentheses. "Mean based on $3 \times 0.25 \mathrm{~m}^{2}$, May $1992 ; \cdots$ mean based on $25 \times 0.1 \mathrm{~m}^{2}$

\begin{tabular}{|c|c|c|c|c|c|c|c|}
\hline \multirow[t]{2}{*}{ Stn } & \multirow{2}{*}{$\begin{array}{l}\text { Lat. (N) } \\
\text { Long. (E) }\end{array}$} & \multirow{2}{*}{$\begin{array}{l}\text { Depth } \\
(\mathrm{m})\end{array}$} & \multicolumn{3}{|c|}{ Arctica islandica } & \multicolumn{2}{|c|}{ Remaining fauna } \\
\hline & & & ind $\mathrm{m}^{-2}$ & AFDW & $\mathrm{FC}$ & ind. $m^{-2}$ & AFDW \\
\hline $\mathrm{H} 3.5$ & $\begin{array}{l}56^{\circ} 04.40^{\prime} \\
11^{\circ} 50.95^{\prime}\end{array}$ & 15 & $\begin{array}{c}38.8 \\
(12.5)\end{array}$ & $\begin{array}{l}16.76 \\
(8.27)\end{array}$ & 91 & $\begin{array}{l}1370 \\
(137)\end{array}$ & $\begin{array}{c}3.22 \\
(1.04)\end{array}$ \\
\hline $\mathrm{H} 3$ & $\begin{array}{l}56^{\circ} 05.20^{\prime} \\
11^{\circ} 50.55^{\prime}\end{array}$ & 17 & $\begin{array}{c}24.0 \\
(11.3)\end{array}$ & $\begin{array}{c}17.18 \\
(13.44)\end{array}$ & 101 & $\begin{array}{c}727 \\
(14.5)\end{array}$ & $\begin{array}{c}7.00 \\
(1.26)\end{array}$ \\
\hline $\mathrm{H} 2.5$ & $\begin{array}{l}56^{\circ} 05.95^{\prime} \\
11^{\circ} 50.10^{\prime}\end{array}$ & 19 & $\begin{array}{c}31.2 \\
(18.2)\end{array}$ & $\begin{array}{c}40.74 \\
(19.95)\end{array}$ & 234 & - & - \\
\hline $\mathrm{H} 2$ & $\begin{array}{l}56^{\circ} 06.75^{\prime} \\
11^{\circ} 49.65^{\prime}\end{array}$ & 22 & $\begin{array}{c}19.6 \\
(12.4)\end{array}$ & $\begin{array}{c}23.13 \\
(22.49)\end{array}$ & 128 & $\begin{array}{c}324 \\
\{25.0\}\end{array}$ & $\begin{array}{c}1.76 \\
(0.49)\end{array}$ \\
\hline $\mathrm{H} 1$ & $\begin{array}{l}56^{\circ} 08.30^{\prime} \\
11^{\circ} 48.90^{\prime}\end{array}$ & 24 & $\begin{array}{c}10.2 \\
\{6.84\}\end{array}$ & $\begin{array}{c}12.50^{\circ} \\
-\end{array}$ & 79 & $\begin{array}{l}1028 \\
(186)\end{array}$ & $\begin{array}{c}6.09 \\
(2.18)\end{array}$ \\
\hline H922 & $\begin{array}{l}56^{\circ} 09.90^{\prime} \\
11^{\circ} 48.00^{\prime}\end{array}$ & 33 & $\begin{array}{c}32.0 \\
(26.8)\end{array}$ & $\begin{array}{c}24.37 \\
-\end{array}$ & 163 & $\begin{array}{l}1585 \\
(213)\end{array}$ & $\begin{array}{c}7.47 \\
(1.88)\end{array}$ \\
\hline
\end{tabular}

Fig. 2. Fluorescence profile in southern Kattegat based on $>600$ profiles measured in March, May and September 1992 (Rasmussen 1994). Means \pm standard deviations (solid and dotted curves) are indicated

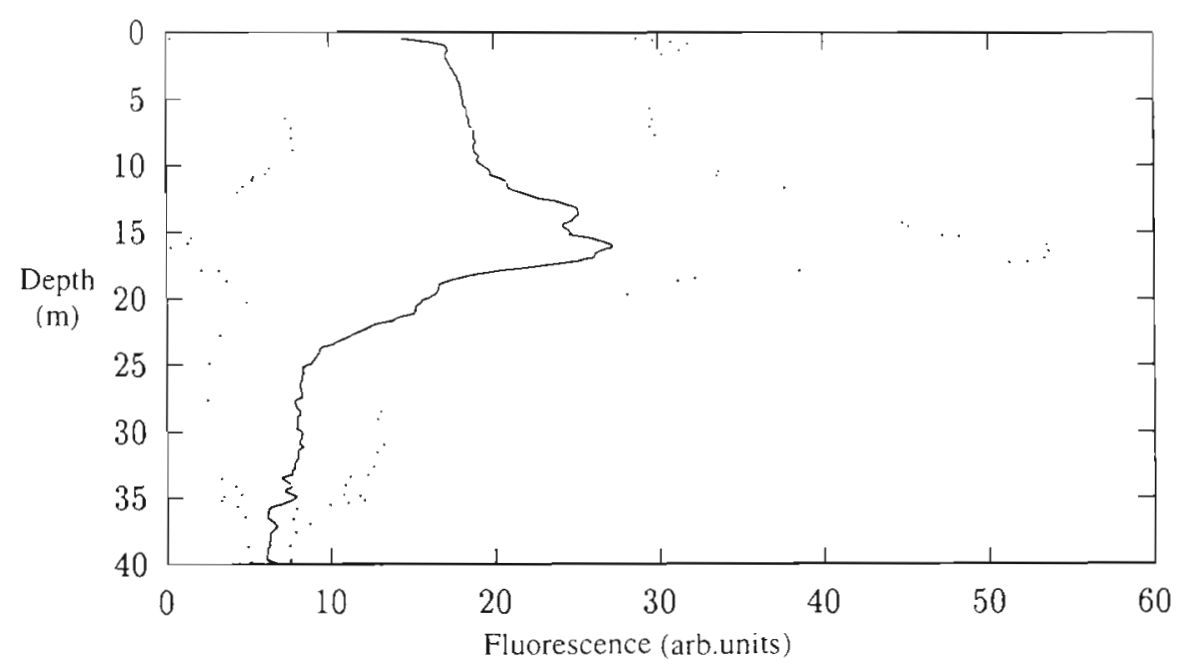

extraction. Extraction volumes varied depending on the size of the individuals. After centrifugation, plant pigments were measured spectrophotometrically (Strickland \& Parsons 1972, Jespersen \& Christoffersen 1987). The content per individual of total chlorophyll was used as a measure of phytoplankton gut content. This measure was considered more conservative than chlorophyll a alone, which is known to be rapidly transformed to phaeopigments in the gut of mussels (Hawkins et al. 1986).

Condition was estimated by means of weight to length relations. Dry weight (DW) of soft tissues was obtained after drying to constant weight at $60^{\circ} \mathrm{C}$. Ashfree dry weight (AFDW) was obtained after ignition for $4 \mathrm{~h}$ at $500^{\circ} \mathrm{C}$.

Growth was estimated through analysis of internal growth bands in the shell (Ropes 1984). For the pur- pose of this study the shell heights from umbo to the first 5 growth bands were used, corresponding to growth during the first to the fifth year of life. Growth during this age period should be solely somatic, since sexual maturity is reached at higher ages (Thomson et al. 1980).

\section{RESULTS}

\section{Macrofaunal communities}

Densities and biomass of Arctica islandica and remaining fauna were estimated from sampling in September 1992, except for Stn H2.5, which was sampled in late May 1992, and only for A. islandica (Table 1). To get an impression of differences in graz- 
Table 2. Bottom water variables in 1992 at 6 stations along the Hesselø transect (means for periods and SD in parentheses, $n=3$ ). Temperature $\left(T_{1}{ }^{\circ} \mathrm{C}\right.$ ), salinity (psu) and chlorophyll ( $\mu \mathrm{g} \mathrm{chl} \mathrm{al}^{-1}$ )

\begin{tabular}{|c|c|c|c|c|c|}
\hline Stn: & $\mathrm{H} 4$ & $\mathrm{H} 3$ & $\mathrm{H} 2$ & $\mathrm{H} 1$ & $\mathrm{H} 922$ \\
\hline \multicolumn{6}{|l|}{ March } \\
\hline $\mathrm{T}$ & $\begin{array}{c}4.28 \\
(0.14)\end{array}$ & $\begin{array}{c}4.71 \\
(0.78)\end{array}$ & $\begin{array}{c}5.46 \\
(0.31)\end{array}$ & $\begin{array}{c}5.61 \\
(0.07)\end{array}$ & $\begin{array}{c}5.56 \\
(0.06)\end{array}$ \\
\hline Salinity & $\begin{array}{l}23.42 \\
(3.21)\end{array}$ & $\begin{array}{l}26.62 \\
(5.63)\end{array}$ & $\begin{array}{l}31.66 \\
(2.58)\end{array}$ & $\begin{array}{l}33.02 \\
(0.38)\end{array}$ & $\begin{array}{c}33.17 \\
(0.39)\end{array}$ \\
\hline Chl a & $\begin{array}{c}4.80 \\
(3.77)\end{array}$ & $\begin{array}{c}8.10 \\
(10.04)\end{array}$ & $\begin{array}{c}5.44 \\
(6.71)\end{array}$ & $\begin{array}{c}2.54 \\
(1.56)\end{array}$ & $\begin{array}{c}1.29 \\
(0.39)\end{array}$ \\
\hline \multicolumn{6}{|l|}{ May } \\
\hline $\mathrm{T}$ & $\begin{array}{c}7.84 \\
(0.66)\end{array}$ & $\begin{array}{c}6.85 \\
(0.98)\end{array}$ & $\begin{array}{c}5.85 \\
(0.09)\end{array}$ & $\begin{array}{c}5.83 \\
(0.01)\end{array}$ & $\begin{array}{c}5.83 \\
(0.03)\end{array}$ \\
\hline Salinity & $\begin{array}{l}24.10 \\
(6.26)\end{array}$ & $\begin{array}{l}31.78 \\
(2.64)\end{array}$ & $\begin{array}{l}33.48 \\
(0.51)\end{array}$ & $\begin{array}{l}33.97 \\
(0.15)\end{array}$ & $\begin{array}{l}33.97 \\
(0.05)\end{array}$ \\
\hline Chl a & $\begin{array}{c}4.42 \\
(1.95)\end{array}$ & $\begin{array}{c}7.90 \\
(5.20)\end{array}$ & $\begin{array}{c}3.70 \\
(2.04)\end{array}$ & $\begin{array}{c}2.50 \\
(0.67)\end{array}$ & $\begin{array}{c}2.06 \\
(0.81)\end{array}$ \\
\hline \multicolumn{6}{|l|}{ September } \\
\hline $\mathrm{T}$ & $\begin{array}{l}15.92 \\
(0.34)\end{array}$ & $\begin{array}{l}13.68 \\
(2.48)\end{array}$ & $\begin{array}{c}9.90 \\
(0.50)\end{array}$ & $\begin{array}{c}9.69 \\
(0.49)\end{array}$ & $\begin{array}{c}9.97 \\
(0.88)\end{array}$ \\
\hline Salinity & $\begin{array}{l}22.51 \\
(1.16)\end{array}$ & $\begin{array}{l}28.19 \\
(6.09)\end{array}$ & $\begin{array}{l}33.16 \\
(0.08)\end{array}$ & $\begin{array}{l}33.23 \\
(0.07)\end{array}$ & $\begin{array}{c}33.23 \\
(0.16)\end{array}$ \\
\hline Chl a & $\begin{array}{c}1.59 \\
(0.33)\end{array}$ & $\begin{array}{c}1.97 \\
(0.27)\end{array}$ & $\begin{array}{c}1.25 \\
(0.32)\end{array}$ & $\begin{array}{c}1.23 \\
(0.50)\end{array}$ & $\begin{array}{c}1.30 \\
(0.84)\end{array}$ \\
\hline
\end{tabular}

particular H1 and H922, were dominated by the passive suspension feeding oph1uroid Amphiura filiformis (Jensen et al. 1994).

\section{Bottom water variables}

In connection with the sampling of the benthos, temperature, salinity and chlorophyll concentrations were measured in the near-bottom water 3 times during each of the cruises (Table 2). Chlorophyll data were analysed with a 2-way ANOVA for effects of season: March/April, May and September, and of station: H4, H3, $\mathrm{H} 2, \mathrm{H} 1$ and $\mathrm{H} 922$ (Table 3). Data were $\ln (x)$ transformed to obtain variances as homogeneous as possible ( $p>0.05$ for station, $\mathrm{p}<0.01$ for seasons, Bartlett's test). Results show a very significant $(p<0.01)$ effect of season and a nearly significant effect of station ( $p=0.056)$, and no interaction between the 2 factors (Table 3). Tukey multiple-range test showed a significant difference between May and Sep-

ing/competition pressure, the filtration capacity of $A$. islandica was calculated using the relation $F=5.55 \times$ DW ${ }^{062}$ where $F$ is filtration rate $\left(\mathrm{l} \mathrm{h}^{-1}\right)$ and DW is $g$ dry wt excluding shell (Møhlenberg \& Riisgård 1979). DW was estimated from the relation between shell length and dry weight (given in Jensen et al. 1994). A. islandica accounted for a major part of the biomass at most stations (ca 70 to $90 \%$ ), and probably also a major part of the competition pressure for suspended organic matter (Table 1). There does not seem to be any clear trend with water depth for any of the faunal variables. The highest mean values of biomass and filtration capacity occurred at Stn H2.5 at $19 \mathrm{~m}$ depth. Biomass of the remaining fauna was dominated by bivalves, both suspension and deposit feeding, at Stns H3.5 and $\mathrm{H} 3$. The biomasses at the deeper stations, H2 and in

Table 3. Results of 2-way ANOVA for effects of season (March/April, May and September) and station (5 stations, $\mathrm{H} 4, \mathrm{H} 3, \mathrm{H} 2, \mathrm{H} 1$ and $\mathrm{H} 922$ ) on bottom water concentrations of chlorophyll a

\begin{tabular}{|lrccc|}
\hline $\begin{array}{l}\text { Source of } \\
\text { variation }\end{array}$ & df & MS & F-ratio & $p$ \\
\hline Season & 2 & 3.14 & 6.11 & 0.006 \\
Stn & 4 & 1.34 & 2.61 & 0.056 \\
Season $\times$ Stn & 8 & 0.10 & 0.19 & 0.990 \\
Error & 29 & 0.51 & & \\
\hline
\end{tabular}

tember $(p=0.005)$, and between March and September $(p=0.035)$, but not between March and May ( $p=$ 0.765). Chlorophyll concentrations were ca 3 times higher in March and May than in September. The mean for March was 4.57, for May 4.12, and for September $1.47 \mu \mathrm{gl}^{-1}$.

The Tukey test on station means showed $p=0.055$ between $\mathrm{H} 3$ and $\mathrm{H} 922$, with the highest value at Stn $\mathrm{H} 3$ at pycnocline depth. Testing with Kendall's rank of concordance ( $p>0.05$ ) suggested the same rank order between the Stns H3, H2 and H922 on 9 occasions, with the highest values at $\mathrm{H} 3$ and lowest at $\mathrm{H} 922$.

\section{Gut content of plant pigments}

In order to investigate if individuals of Arctica islandica in the area where the pycnocline has contact with the bottom had an increased content of plant pigments, total chlorophyll was measured in individuals from the Stns H3, H2 and H922 on 3 different occasions in 1992. Individuals with shell lengths $<40 \mathrm{~mm}$ were selected to get the best possible balance between the number of observations from different stations (a length of $40 \mathrm{~mm}$ roughly corresponds to an age of $5 \mathrm{yr}$ ).

Individual chlorophyll content plotted against shell length is shown for each of the 3 sampling dates in Fig. 3. The highest individual values in relation to 

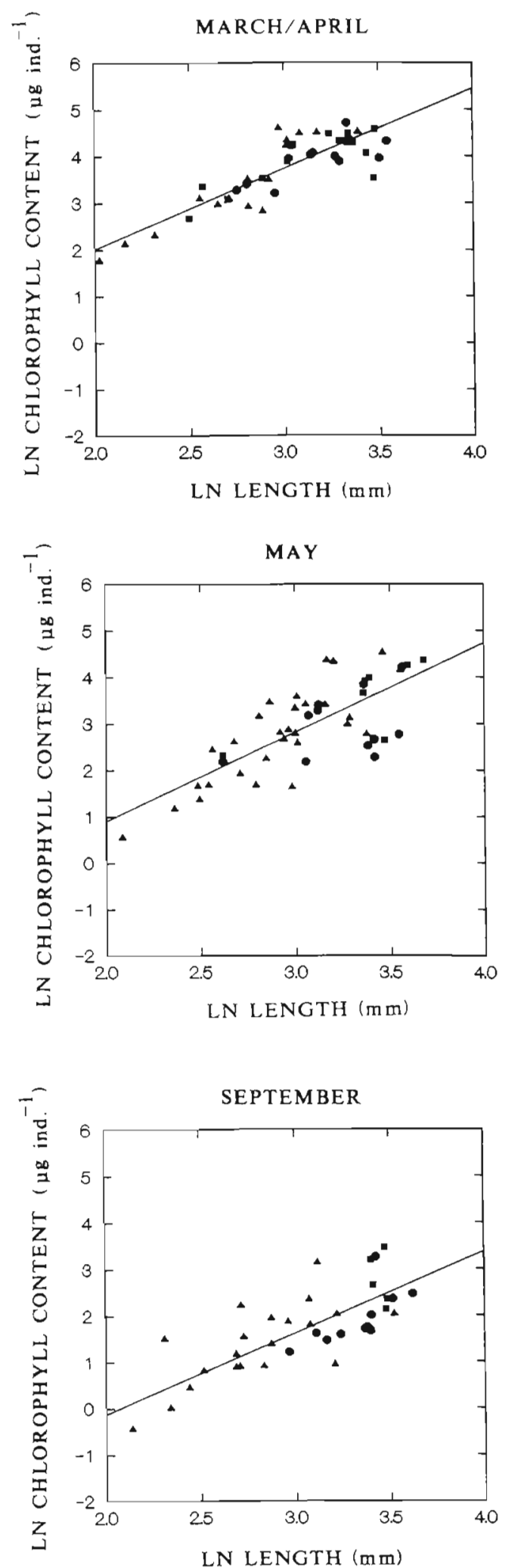

Fig. 3. Arctica islandica. Individual content of total chlorophyll plotted against shell length from 3 dates in 1992, at Stn $\mathrm{H} 3(\mathbf{4})$, Stn $\mathrm{H} 2(\bullet)$ and Stn $\mathrm{H} 922$ length occurred at station H3 in May and September. A 2-way ANCOVA was used to test for effects of season/date using the 3 dates March/April, May and September, and for the effects of the 3 stations ( $\mathrm{H} 3, \mathrm{H} 2$ and H922) on total chlorophyll content in the mussels with shell length as a covariate (Table 4). Residuals for relations between chlorophyll content and shell length from each date and station were a priori checked for homogeneity through inspection of plots. Results from testing for homogeneity of slopes showed no interaction between season and length, whereas the interaction term for station and length was close to significant.

The subsequent analysis of covariance showed highly significant differences in intercepts for season, and no interaction between station and season. The concentration in March/April was higher than in May (ca 3 times), which was higher than in September ( 3 to 4 times) (Fig. 3). The concentration in March/April was ca 7 times higher than in September.

\section{Condition}

Condition was estimated by the relation between soft tissue AFDW and shell length on materials from the 3 stations $\mathrm{H} 3, \mathrm{H} 2$, and H922. Testing with 2-way ANCOVA for effects of season and station with shell length as a covariate showed significant effects of both treatments, but the slopes differed significantly with respect to season, and the interaction term for stations was close to being significant $(\mathrm{p}=0.055)$ (Table 5). Furthermore, there was significant interaction between season and station. In any event, differences between

Table 4. Arctica islandica. Results of 2-way ANCOVA for effects of season (March/April, May and September) and station ( $\mathrm{H} 3, \mathrm{H} 2$ and 922) on total chlorophyll $(\ln x)$ in A. islandica with in shell length as a covariate

\begin{tabular}{|c|c|c|c|c|}
\hline $\begin{array}{l}\text { Source of } \\
\text { variation }\end{array}$ & $\mathrm{df}$ & MS & F-ratio & $\mathrm{p}$ \\
\hline \multicolumn{5}{|c|}{ Test for homogeneity of slopes } \\
\hline Season & $2^{2}$ & 0.69 & 2.52 & 0.085 \\
\hline Stn & 2 & 0.58 & 2.11 & 0.125 \\
\hline Length & 1 & 25.65 & 93.41 & 0.000 \\
\hline Season $\times$ Length & 2 & 0.08 & 0.30 & 0.741 \\
\hline Stn $\times$ Length & 2 & 0.75 & 2.72 & 0.070 \\
\hline Error & 119 & 0.28 & & \\
\hline \multicolumn{5}{|c|}{ Analysis of covariance } \\
\hline Season & 2 & 34.86 & 122.92 & 0.000 \\
\hline Stn & 2 & 1.56 & 5.49 & 0.005 \\
\hline Length & 1 & 51.33 & 181.01 & 0.000 \\
\hline Season $\times$ Stn & 4 & 0.14 & 0.48 & 0.751 \\
\hline Error & 119 & 0.28 & & \\
\hline
\end{tabular}


Table 5. Arctica islandica. Results of 2-way ANCOVA for effects of station (H3, H2, H922) and date (March/April, May and September) on individual weight [In(AFDW)] with In(shell length) as a covariate

\begin{tabular}{|c|c|c|c|c|}
\hline $\begin{array}{l}\text { Source of } \\
\text { variation }\end{array}$ & $\mathrm{df}$ & MS & $F$-ratio & $\mathrm{p}$ \\
\hline \multicolumn{5}{|c|}{ Test for homogeneity of slopes } \\
\hline Stn & 2 & 0.21 & 4.65 & 0.011 \\
\hline Season & 2 & 0.12 & 2.74 & 0.067 \\
\hline Length & 1 & 434.42 & 9846.94 & 0.000 \\
\hline Stn $\times$ Length & 2 & 0.13 & 2.94 & 0.055 \\
\hline Season $\times$ Length & 2 & 0.17 & 3.84 & 0.023 \\
\hline Error & 214 & 0.04 & & \\
\hline \multicolumn{5}{|c|}{ Analysis of covariance } \\
\hline Stn & 2 & 0.43 & 9.63 & 0.000 \\
\hline Season & 2 & 0.42 & 9.40 & 0.000 \\
\hline Length & 1 & 564.91 & 12587.29 & 0.000 \\
\hline Stn $\times$ Season & 4 & 0.13 & 2.82 & 0.026 \\
\hline Error & 214 & 0.05 & & \\
\hline
\end{tabular}

treatments, if present, were very small, suggested by a good fit for the total material regressed against length IAFDW $(\mathrm{g})=0.000004676 \times$ Shell length $(\mathrm{mm})^{3084}, \mathrm{R}^{2}=$ $0.98, \mathrm{n}=281]$.

\section{Growth}

Growth was estimated by measuring internal growth bands in the shell. Shell height plotted against age, for the first $5 \mathrm{yr}$, is shown for each station in Fig. 4 . The plot suggest a linear increase in size with age, and an arched pattern with high values at the stations at intermediate depths. Regression analysis on the total material and the stations individually showed a good fit to a linear model $y=a+b x$, where $b$ equals the growth rate

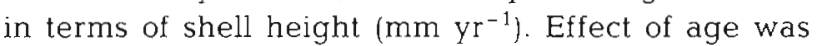
significant (ANOVA) in all cases (Table 6.). Fitting the stations individually reduced the residual variation with ca $30 \%$ compared to fitting the total material, and ANCOVA showed highly significant interaction between water depth and age ( $p<0.001)$, suggesting a clear effect of water depth on increase in shell height. Growth rates, that is, slopes in the linear relations between height and age, are plotted against water depth in Fig. 5. Highest growth rates occurred at Stns $\mathrm{H} 2$ and $\mathrm{H} 2.5$ at 22 and $19 \mathrm{~m}$ water depth, and the lowest at Stns H3.5 and H922 at 15 and 33 m respectively. Highest rates were ca $40 \%$ higher than the lowest ones. This difference in terms of production of soft tissue was $>100 \%$, using the relation between ash-free dry weight and shell length (above) and the linear relation between shell height and shell length [Length $(\mathrm{mm})=$ $1.134 \times$ Height $\left.(\mathrm{mm})+0.90, n=80, \mathrm{R}^{2}=0.996\right]$.

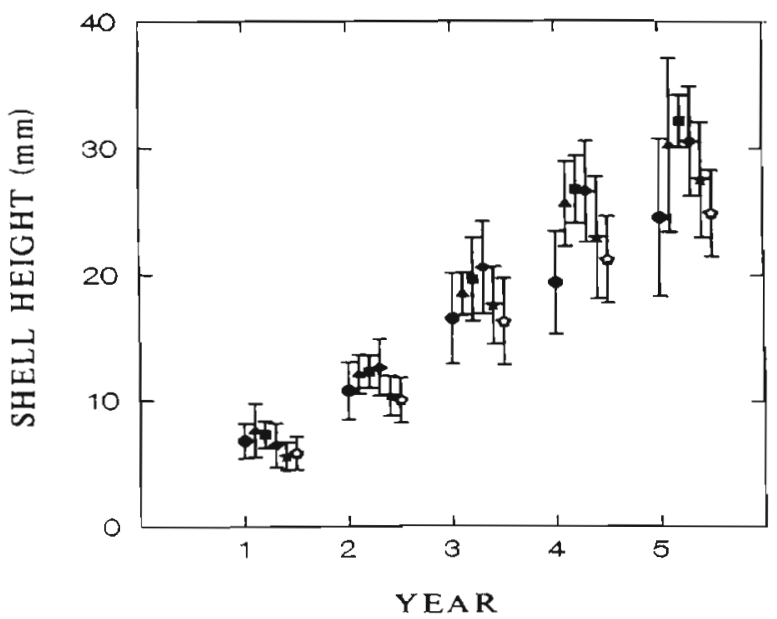

Fig. 4. Arctica islandica. Shell height for the first 5 annual growth bands ( $\pm \mathrm{SD}$ ) at $\mathrm{Stn} \mathrm{H} 3.5(\bullet)$, Stn $\mathrm{H} 3(\mathbf{\Delta}), \mathrm{Stn} \mathrm{H} 2.5(\square)$, Stn $\mathrm{H} 2(\bullet)$, Stn $\mathrm{H} 1(\star)$, and Stn $\mathrm{H}_{2} 22(\bullet)$

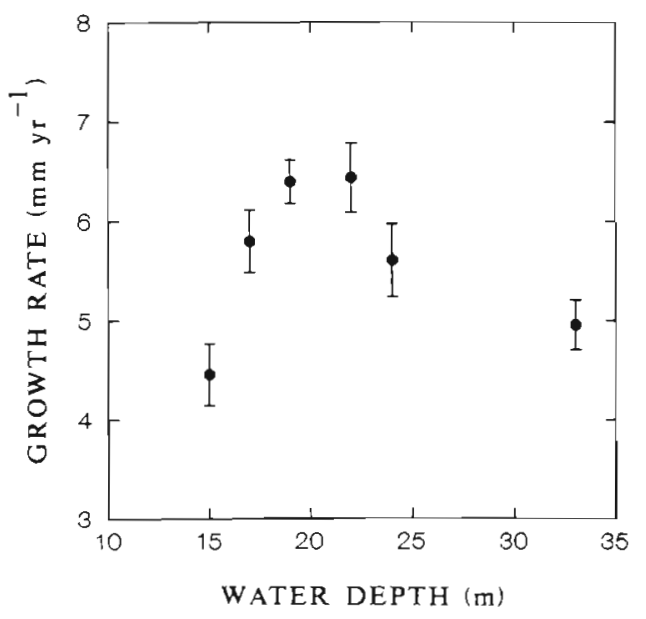

Fig. 5. Arctica islandica. Growth rates in terms of shell height for the 5 first yr of life plotted against water depth. Error bars denote $2 \mathrm{SE}$

Differences in growth between stations thus explain ca $30 \%$ of the residual variation when effects of age were removed, leaving $70 \%$ unexplained. Since the material used contains individuals of different ages, one obvious source of variation could be temporal variations in growth conditions. To explore this possibility, individuals which could be aged accurately were selected from the 2 stations $\mathrm{H} 2$ and $\mathrm{H} 2.5$ where growth rates were similar (Fig. 5). Shell height increments from the first 5 yr of life, when growth was linear, was used. Mean increments with error bars (2 SE) are shown for the years 1985 to 1991 in Fig. 6. One-way ANOVA showed a nearly significant effect of year ( $p=$ $0.075, n=63, R^{2}=0.18$ ). Increments were great in 1986 and 1990 and low in 1988 and 1991. The highest 
Table 6 . Results of linear regression $(y=a+b x)$ analysis between shell height $(y)$ and age $(x)$ the first 5 yr of life. $b$ equals growth rate $\left(\mathrm{mm} \mathrm{yr}^{-1}\right)$. Effects of model highly significant (ANOVA, $\mathrm{p}<0.001$ ) in all cases. SS: sum of squares; df: degrees of freedom

\begin{tabular}{|c|c|c|c|c|c|c|c|}
\hline \multirow[t]{2}{*}{ Material } & \multirow[t]{2}{*}{$a$} & \multirow[t]{2}{*}{$b$} & \multirow[t]{2}{*}{$\mathrm{R}^{2}$} & \multicolumn{2}{|c|}{ Model } & \multicolumn{2}{|c|}{ Residual } \\
\hline & & & & $\mathrm{df}$ & SS & df & SS \\
\hline Stn H3.5 & 2.29 & 4.46 & 0.80 & 1 & 1655 & 52 & 422 \\
\hline $\mathrm{Stn} \mathrm{H} 3$ & 1.34 & 5.80 & 0.89 & 1 & 2490 & 43 & 316 \\
\hline $\mathrm{Stn} \mathrm{H} 2.5$ & 0.40 & 6.40 & 0.94 & 1 & 4042 & 52 & 243 \\
\hline $\mathrm{Stn} \mathrm{H} 2$ & 0.21 & 6.44 & 0.89 & 1 & 3110 & 43 & 393 \\
\hline Stn $\mathrm{H}_{1}$ & 0.10 & 5.61 & 0.88 & 1 & 2167 & 33 & 311 \\
\hline Stn H92.2 & 0.82 & 4.95 & 0.86 & 1 & 2988 & 62 & 471 \\
\hline Sum stns & & & & & 16452 & & 2156 \\
\hline Total material & 1.01 & 5.54 & 0.85 & 1 & 16540 & 295 & 3040 \\
\hline
\end{tabular}

annual growth (1990) was ca 7.5 and the lowest 5.5 (1988), suggesting an absolute inter-annual variation of $\pm 1 \mathrm{~mm}$ shell height $\mathrm{yr}^{-1}$, which is the same magnitude as station-effect differences.

\section{DISCUSSION}

Chlorophyll concentrations in the bottom water and chlorophyll gut content in the bivalves showed a similar seasonal pattern, which would be expected if ingestion is related to water chlorophyll concentrations. Differences in these variables among stations, however, could not be statistically confirmed, even if mean values of bottom water chlorophyll and gut content seemed to suggest highest values at Stn H3. Differences in condition among stations could not be statistically confirmed, and were, if they existed, small. A sig-

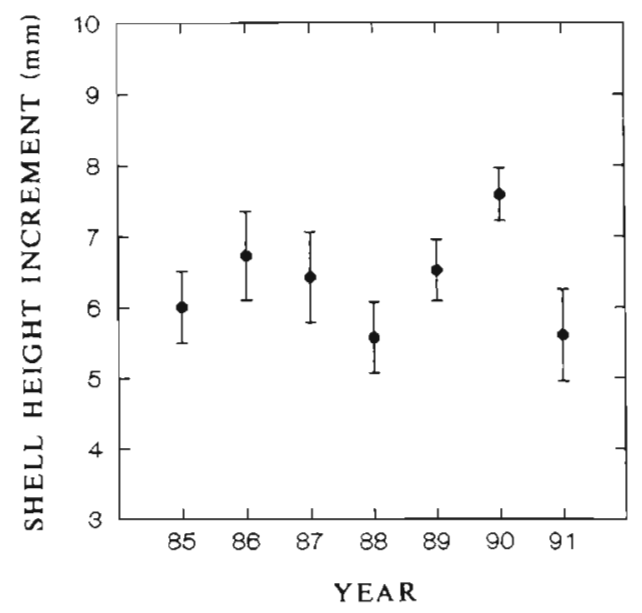

Fig. 6. Arctica islandica. Shell height increments from the first 5 yr of life from Stns H2 and H2.5 for the years 1985-91. Error bars denote 2 SE. ANOVA showed close to significant ( $\mathrm{p}<$ $0.075, \mathrm{n}=63$ ) difference between years nificant part of the variation in size, ca $30 \%$ of residual variation when effects of age was removed, could be explained by differences among stations. Shell growth was highest immediately below pycnocline depth. The data suggest that variation due to station/depth was of similar magnitude as temporal variations in growth in 1985 to 1991 .

The 3 different measures used represent conditions for 3 different time scales: hours or days for gut content, months for condition, and several years for the growth estimates. Growth would be expected to be the most accurate in reflecting an annually re-occurring, but within the year variable, food gradient, because it is an integrated measure covering several years. Indeed, our results suggest the clearest pattern using shell growth. In addition, for condition, as measured here, to be useful as a measure for tissue growth, it requires that there is a time lag between biomass growth and shell growth, as seen in Mytilus edulis (Hilbish 1986). This has not been reported for this species.

The main signal, thus, seems to be a stimulation of growth at depths immediately below pycnocline depth. Previous work has shown positive correlations between infaunal bivalve growth and seasonally varying chlorophyll input to the sediment (Christensen \& Kanneworff 1985) and diatom availability in the near bottom water (Beukema \& Cadée 1991). Growth has also successfully been used to demonstrate resource competition among infaunal filter feeding bivalves (Petersen \& Black 1987). These studies add support to the view that growth may be a useful variable in reflecting availability of high quality organic matter close to the bottom. If we accept that growth differences among stations from pycnocline depth and deeper is a result of differential input of organic material, such as phytoplankton, to the bottom, our results suggest, all else being equal, a $>100 \%$ higher input in the area where highest growth rates were observed. 
This estimation is at least not biased by reproduction since only immature individuals have been analysed (Thompson et al. 1980).

The relative differences in growth among stations in our study are of the same order of magnitude as differences in terms of bottom water chlorophyll in March and May 1992 (Table 2) and fluorescence (Fig. 2), 100 to $200 \%$. Growth differences are also of a similar magnitude as differences in particulate organic carbon (POC) concentrations between water at pycnocline depth and the bottom water in 1989 in the same area (Olesen \& Lundsgaard 1992). These authors reported values $50 \%$ higher in the 10 to $15 \mathrm{~m}$ depth interval compared to the 15 to $30 \mathrm{~m}$ interval.

Although growth differences and differences in organic matter between the pycnocline area and deeper layers are of similar magnitude, there is a discrepancy between the growth and the fluorescence distributions. Despite highest fluorescence values at depths of 15 to $17 \mathrm{~m}$, shell growth is highest somewhat deeper than the average position of the pycnocline, at 19 to $22 \mathrm{~m}$ depth. As such, these results do not support the expectation of a simple direct relation between pycnocline production and Arctica islandica growth. Consequently, we discuss alternative explanations of the growth pattern.

In contrast to growth estimates, the fluorescence distribution and chlorophyll estimations in the bottom water, which represent the situation during 3 cruises in 1992, may not be representative over a longer time period. The position of the pycnocline may vary depending on the input of fresh water to the Kattegat (Pedersen \& Møller 1981). Shell growth may also be negatively affected by the lower salinity ( 5 to $10 \mathrm{psu}$ Table 2) above the pycnocline. Although a lower maximum size has been reported from the mesohaline area of Kiel Bay, early growth does not seem to differ substantially from our figures (Brey et al. 1990). We cannot, however, rule out the possibility that the high salinity variation as such which characterizes the pycnocline area may affect shell growth negatively.

One factor contributing to high growth below the peak of fluorescence could be hypoxia-induced elimination of competing fauna. Oxygen measurements in the bottom water in 1992 (Nielsen et al. 1994) showed a marked decrease in the sub-pycnocline water, and the low(est) values were always measured at Stn $\mathrm{H} 2$ at $22 \mathrm{~m}$ depth, which rarely (if ever) is positioned above the pycnocline. In 1992 the remaining fauna showed significantly lower biomass at Stn $\mathrm{H} 2$ at $22 \mathrm{~m}$ depth compared to all other stations (Table 1). Compared to the competition pressure exerted by Arctica islandica itself, however, as assessed by filtration capacity (Table 1), the remaining fauna is probably of minor importance. Intra-specific competition is not likely to explain differences in growth between stations, since neither density nor biomass/filtration rates are lower where growth is high (Table 1).

It is furthermore not clear if there is a direct relationship between fluorescence and the food utilized by Arctica islandica. It is possible that partly decomposed algal matter with less chlorophyll is high immediately below the pycnocline. This situation would tend to increase growth relative to fluorescence below the pycnocline.

Temperature may affect growth, but differences between stations at a given date were small (Table 2; Nielsen et al. 1994); moreover, the growth was lower both above (Stn H3.5) and below average pycnocline depth, which would contradict the assumption that differences between stations were primarily temperature determined. Resuspension is one factor positively affecting the opportunity for filter feeders to obtain food. Resuspension frequency in the actual area is more or less negatively dependent on water depth (Floderus \& Pihl 1990), and highest resuspension would be ex-pected to occur at the shallowest station (H3.5), where growth was low.

The long-term temporal pattern in growth is difficult to interprete because environmental data on interannual variations are lacking from the actual stations. We know that oxygen conditions were poor in 1988 at adjacent stations (Kronvang et al. 1993), when growth was low, but growth was also low in 1991 when oxygen concentrations did not reach the same low levels as in 1988 (G. Ertebjerg unpubl.).

The degree to which our results on Arctica islandica can be extrapolated to a larger area and a greater part of the benthic community remains to be investigated. One way to test the causal relationship between pycnocline production and the benthic system could be to compare pelagic and benthic production in areas with different average positions of the pycnocline.

Previous work suggests that the sedimenting spring bloom may be a major source of energy that rapidly reaches the benthic system in open coastal areas (e.g. Graf et al. 1982, Christensen \& Kanneworff 1985,1986$)$. In principle, the pycnocline production should represent an important additional direct channel of energy from the pelagic to the benthic system in parts of some open sea areas, which in contrast to the sedimenting spring bloom is open during a greater part of the year. Although not demonstrating a simple direct relation between pycnocline production and benthic energy demand, our results suggest differential availability of organic matter for the benthos that is difficult to explain by a depth alone, and highlight the need for further work to reveal mechanisms in the coupling between pelagic and benthic productivity. 
Acknowledgements. Financial support was given from the Danish Hav90 programme (contracts no. 2.35 to A.B.J., 2.34 to T.G.N, and 2.36 to B.R.). We thank Kurt T. Jensen for valuable comments on an earlier version, Birgit Soborg, Heike Penzien. Gitte Nielsen and Kristine Garde for technical assistance, and especially Grete Dinesen for skilful assistance in connection with growth estimations.

\section{LITERATURE CITED}

Baden SP, Loo LO, Pihl L, Rosenberg R (1990) Effects of eutrophication on benthic communities including fish: Swedish west coast. Ambio 19:113-122

Beukema JJ, Cadée GC (1991) Growth rates of the bivalve Macoma balthica in the Wadden Sea during a period of eutrophication: relationships with concentrations of diatoms and flagellates. Mar Ecol Prog Ser 68:249-256

Brey T, Arntz WE, Pauly D, Rumohr H (1990) Arctica (Cyprina) islandica in Kiel Bay (Western Baltic): growth, production and ecological significance. $\mathrm{J}$ exp mar Biol Ecol 136:217-235

Christensen H, Kanneworff E (1985) Sedimenting phytoplankton as major food source for suspension and deposit feeders in the Øresund. Ophelia 24:223-244

Christensen H, Kanneworff E (1986) Sedimentation of phytoplankton during a spring bloom in the Øresund. Ophelia 26:109-122

Floderus S, Pihl L (1990) Resuspension in the Kattegat: impact of variation in wind climate and fishery. Estuar coast Shelf Sci $31: 487-498$

Graf G, Bengtsson W, Diesner U, Schulz R, Theede H (1982) Benthic response to sedimentation of a spring phytoplankton bloom: process and budget. Mar Biol 67:201-208

Hawkins AJS, Bayne BL, Mantoura RFC, Llewellyn CA (1986) Chlorophyll degradation and absorption throughout the digestive system of the blue mussel Mytilis edulis L. J exp mar Biol Ecol 96:213-223

Hilbish TJ (1986) Growth trajectories of shell and soft tissue in bivalves Seasonal variation in Mytilis edulis L. J exp mar Biol Ecol 96:103-113

Hundahl H, Holck J (1980) A new in situ fluorimeter for detection of Rodamine B and chlorophyll. Rep No 42, Inst of Physical Oceanography, University of Copenhagen, $p$ $145-154$

Jensen JN, Josefson AB, Dinesen G (1994) Effekter af sringlagsopblomstring på benthos. Havforskning fra Miljøstyrelsen, Nr 34, Miljøstyrelsen, Copenhagen

Jespersen AM, Christoffersen K (1987) Measurements of chlorophyll a from phytoplankton using ethanol as extrac- tion solvent. Arch Hydrobiol 109:445-454

Josefson AB, Jensen JN (1992) Effects of hypoxia on softsediment macrobenthos in southern Kattegat, Denmark. In: Colombo G, Ferrari l, Ceccherelli VU, Rossi R (eds) Marine eutrophication and population dynamics. Olsen \& Olsen, Fredensborg, p 21-28

Kronvang B, Ertebjerg G, Grant R, Kristensen P, Hovmand $M$, Kirkegård J (1993) Nationwide monitoring of nutrients and ecological effects: state of the Danish aquatic environment. Ambio 22:176-187

Mahlenberg F. Riisgård HU (1979) Filtration rate, using a new indirect technique, in thirteen species of suspensionfeeding bivalves. Mar Biol 54:143-148

Nielsen TG, Bjornsen PK, Kaas H, Rasmussen B, Cohen A (1994) Planktondynamik omkring springlaget i Kattegat Havforskning fra Miljostyrelsen, Nr 33. Miljøstyrelsen, Copenhagen

Olesen M. Lundsgaard C (1992) Sedimentation af organisk materiale fra den fotiske zone i det sydlige Kattegat. In: Fenchel $\mathrm{T}$ (ed) Planktondynamik og stofomsetning i Kattegat. Havforskning fra Miljøstyrelsen, $\mathrm{Nr}$ 10, Miljøstyrelsen, Copenhagen, p 167-183

Pedersen FB, Møller JS (1981) Diversion of the River Neva. How it will influence the Baltic Sea, the Belts and Cattegat. Nord Hydrol 12:1-20

Peterson $\mathrm{CH}_{1}$ Black R (1987) Resource depletion by active suspension feeders on tidal flats: influence of local density and tidal elevation. Limnol Oceanogr 32:143-166

Rasmussen B (1994) Blandningsmekanismer i kystnæere farvande. Havforskning fra Miljøstyrelsen, Nr 32. Miljøstyrelsen, Copenhagen

Richardson K, Christoffersen A (1991) Seasonal distribution and production of phytoplankton in the southern Kattegat. Mar Ecol Prog Ser 78:217-227

Ropes JW (1984) Procedures for preparing acetate peels and evidence validating the annual periodicity of growth lines formed in the shells of ocean quahogs, Arctica islandica. Mar Fish Rev 46:27-35

Rosenberg R, Loo LO (1988) Marine eutrophication induced oxygen deficiency: effects on soft bottom fauna, western Sweden. Ophelia 29:213-225

Rosenberg R, Möller P (1979) Salinity stratified benthic macrofaunal communities and long-term monitoring along the west coast of Sweden. J exp mar Biol Ecol 37 : $175-203$

Strickland JDH, Parsons TR (1972) A practical handbook of seawater analysis. Bull Fish Res Bd Can 167:1-310

Thompson 1, Jones DS, Dreibelbis D (1980) Annual internal growth banding and life history of the ocean quahog Arctica islandica (Mollusca: Bivalvia). Mar Biol 57:25-34

Manuscript first received: November 22, 1994

Revised version accepted: April 7, 1995 